\title{
Removal of heavy metals by Escherichia coli $(E$. coli) biofilm placed on zeolite from aqueous solutions (case study: the wastewater of Kerman Bahonar Copper Complex)
}

\author{
Ahmad Khosravi ${ }^{1} \cdot$ Marzieh Javdan $^{2} \cdot$ Ghazal Yazdanpanah $^{3} \cdot$ Mohammad Malakootian $^{2,3}$ (D)
}

Received: 6 August 2017 / Accepted: 12 June 2020 / Published online: 23 June 2020

(c) The Author(s) 2020

\begin{abstract}
Industrial wastewater needs to be treated because of the heavy metals presence and their effects on the environment. The aim of this study was to remove heavy metals ions such as copper and zinc from aqueous solutions by using Escherichia $\operatorname{coli}($ E. coli) biofilm which was placed on zeolite. The paper was experimental. Synthetic and real samples were evaluated in laboratory scale. To evaluate the removal efficiency, the effective parameters such as $\mathrm{pH}$, copper and zinc concentrations, and contact time were examined. Optimal conditions were obtained with experiments on the synthetic samples. To study the adsorption isotherms, Langmuir and Freundlich isotherm models were investigated. The copper and zinc cations maximum removal efficiency at $40 \mathrm{mg} / \mathrm{L}$ within 10 days was obtained as $54.61 \%$ and $57.35 \%$, respectively. By using Langmuir isotherm, the experimental data were fitted with correlation coefficients of 0.98 and 0.95 for copper(II) and zinc(II), respectively. The results showed that the hybrid of zeolite and bacterial biofilm system has the best efficiency for removing the metal copper and zinc cations.
\end{abstract}

Keywords Biosoprtion $\cdot$ Heavy metals $\cdot$ Zeolite $\cdot$ Escherichia coli

\section{Introduction}

Heavy metals because of some properties such as non-biodegradability, toxicity, tendency to accumulate in photosynthetic organism and eventually presence in the food chain (even at low concentrations in the environment) cause pollutants transfer to humans (Malakootian et al. 2008; Kamsonlian et al. 2011; Silva et al. 2012; Munoz et al. 2012). Zinc is one of the essential elements for living organisms (Fu and Wang 2011; Plaza et al. 2012), but in the higher concentrations, it is toxic and causes electrolytes imbalance, loss of muscle coordination, stomach cramps, skin inflammation,

Mohammad Malakootian

m.malakootian@yahoo.com

1 Leishmaniasis Research Center, Kerman University of Medical Sciences, Kerman, Iran

2 Department of Environmental Health, School of Public Health, Kerman University of Medical Sciences, Kerman, Iran

3 Environmental Health Engineering Research Center, Kerman University of Medical Sciences, Kerman, Iran vomiting, nausea and anemia (Malakootian et al. 2015a, b; Plaza et al. 2012; Diagomanolin et al. 2004; Ahmadi et al. 2017).

Copper is necessary for human metabolism too, but intake of extra copper causes vomiting, muscle cramps, convulsion and even death (Fu and Wang 2011). According to the US Environmental Protection Agency (US EPA) standard, the maximum allowable levels for copper and zinc cations in drinking water are 5 and $0.5 \mathrm{mg} / \mathrm{L}$, respectively (Plaza et al. 2012).

Various methods including ion exchange, filtration, coagulation, adsorption, and electrochemical deposition have been used for treatment of effluents containing heavy metals (Kamsonlian et al. 2011; Malakootian et al. 2015a, b; Plaza et al. 2012; Rosales et al. 2011). Adsorption and ion exchange are considered as typical (Figueiredo et al. 2010) and economical methods with simple and effective operation (Rosales et al. 2011).

Due to the need for environmentally friendly technologies, the use of microorganisms for heavy metals removal has paid attention (Wang et al. 2012; Quintelas et al. 2013). The microorganism's cellular wall has polysaccharides, proteins, fats and functional groups, which tend to react with 
metal ions (Silva et al. 2012; Munoz et al. 2012). Adsorbents have some advantages such as inexpensiveness, abundance and accessibility, low production of biological and chemical sludge, recovery of the biosorbents and metals, not producing secondary contaminations and being environmentaly friendly (Malakootian et al. 2012; Munoz et al. 2012; Wang et al. 2013; Tavares et al. 2006). Among various microorganisms, bacteria have a lot of characteristics such as high surface-to-volume ratio, wide presence in various environments, capability in production of macromolecules called extracellular polymeric substances (EPSs) which make them reliable and applicable biosorbents (Quintelas et al. 2008, 2009a, b).

Suspended biofilms alone are not able to adsorb pollutants constantly and also there is a possibility of their discharge from the reactor which could cause reduction in efficiencies and make operational problems. Hence, most of the time fixed beds are used to preserve biofilms (Quintelas et al. 2009a, b; Lameiras et al. 2008). Materials with adsorption properties for biofilms and contaminants as well as porous structures are suitable options. Negative charge due to the zeolite structure reaches equilibrium through bonding between exchangeable cations (sodium, potassium, calcium), so there is high tendency for metal cations transferring (Quintelas et al. 2009a, b; Lameiras et al. 2008).

The aim of this study was to remove heavy metals ions such as copper and zinc from aqueous solutions by using $E$. coli biofilm which was placed on zeolite and investigation of its aggravating effect with zeolite. To optimize the metal ions removal efficiency by bacterial biofilm mixed with zeolite, the effects of different parameters including the initial concentration of copper and zinc, $\mathrm{pH}$ and contact time were studied. Also, the adsorption equilibrium isotherms models were evaluated. Furthermore, the efficiency of the bacteriazeolite system for treatment of raw wastewater and treated industrial wastewater was evaluated.

\section{Materials and methods}

An experimental study was conducted on synthetic and real samples in the Environmental Health Engineering Research Center at Kerman University of Medical Sciences.

The real sample was taken from Bahonar Copper Complex (Kerman, Iran). Zeolite was purchased from Research Center of Jajarm Steel Complex. Before using zeolite, it was heated at $500{ }^{\circ} \mathrm{C}$ for $8 \mathrm{~h}$ in the furnace. Deionized water (DI water) was used for prepare solutions. X-Ray fraction (XRF) and X-Ray diffraction (XRD) methods were used for chemical analysis and determination of the phases in the zeolite sample. $\mathrm{Cu}(\mathrm{II})$ and $\mathrm{Zn}(\mathrm{II})$ stock solutions $(1000 \mathrm{mg} / \mathrm{L})$ were prepared by dissolving the salts of copper chloride $\left(\mathrm{CuCl}_{2}\right)$ and zinc sulfate $\left(\mathrm{ZnSO}_{4}\right)$ in the DI water.
Microbial samples were taken from four points of input neutralization, output neutralization, the regional soil (irrigated by wastewater) and the output wastewater of the treatment plant (used for irrigation purposes).

The microbial samples were collected in the sterilized glass containers. Also, the soil samples were taken with gloves and sterilized spatula from a depth of $0-20 \mathrm{~cm}$. Then, the collected samples were transferred to laboratory in the vicinity of ice and kept in refrigerator at $4{ }^{\circ} \mathrm{C}$.

At first, the real sample chemical quality was determined. Atomic absorption device (YOUNCLIN AAS 8020) was used to measure the copper and zinc concentrations at the wavelengths of $324.70 \mathrm{~nm}$ and $213.90 \mathrm{~nm}$ for copper and zinc, respectively. All of the experiments were conducted according to the Standard Methods of Water and Wastewater Experiments, Edition 20 (APHA 1999).

In order to eliminate any possible disturbance, the calibration curves of various concentrations were plotted. To remove other interfering metals, all of the glass containers which used in this study were washed with nitric acid $10 \%$ and deionized distilled water. Adsorption experiments were carried out to determine the adsorption equilibrium time, optimal conditions ( $\mathrm{pH}$, contact time and concentration of copper and zinc) and study of the adsorption isotherm models. The $\mathrm{pH}$ values of the samples were adjusted with $\mathrm{H}_{2} \mathrm{SO}_{4}$ and $\mathrm{NaOH} 0.1 \mathrm{~N}$. Measurements of $\mathrm{pH}$ values were done with digital $\mathrm{pH}$ meter (Hanna 211). The removal efficiencies were evaluated at $\mathrm{pH}=3-9$, initial concentration of copper and zinc $(10-60 \mathrm{mg} / \mathrm{L})$ and contact time of 10 days. The optimal conditions for each parameter were determined. All of the experiments were done in the incubator shaker at $150 \mathrm{rpm}$ and $28{ }^{\circ} \mathrm{C}$. The copper and zinc $\left(q_{\mathrm{e}}\right)$ adsorption capacity is evaluated by Eq. (1):

$q_{\mathrm{e}}=\frac{\left(C_{\mathrm{i}}-C_{\mathrm{e}}\right) V}{m}$

where $q_{\mathrm{e}}$ is the $\mathrm{mg} / \mathrm{g}$ of the adsorbent, $C_{\mathrm{i}}$ represents the initial concentration of the metal in terms of $\mathrm{mg} / \mathrm{L}, C_{\mathrm{e}}$ shows the remaining concentration at the time of equilibrium in terms of $\mathrm{mg} / \mathrm{L}, V$ denotes the volume of the solution in terms of $L$, and $m$ is the amount of adsorbent in terms of $g$.

To characterize the adsorption isotherms of $\mathrm{Cu}^{2+}$ and $\mathrm{Zn}^{2+}$ by $E$. coli biofilm placed on zeolite, two common isotherm models including Freundlich and Langmuir models were used that their linear forms are presented as Eqs. (2) and (3), respectively:

$$
\begin{aligned}
& \log q_{\mathrm{e}}=\log k_{\mathrm{f}}+\frac{1}{n} \log C_{\mathrm{e}} \\
& \frac{C_{\mathrm{e}}}{q_{\mathrm{e}}}=\frac{1}{K_{\mathrm{L}} q_{\mathrm{m}}}+\frac{C_{\mathrm{e}}}{q_{\mathrm{m}}}
\end{aligned}
$$


where $K_{\mathrm{F}}$ and $n$ are the Freundlich model constants indicating adsorption capacity and intensity, respectively, $C_{\mathrm{e}}$ $(\mathrm{mg} / \mathrm{L})$ is the equilibrium concentration; $q_{\mathrm{m}}(\mathrm{mg} / \mathrm{g})$ is the maximum adsorption capacity; $b(\mathrm{~L} / \mathrm{mg})$ is the Langmuir constant as a function of the adsorption energy.

\section{Separation of E. coli}

In order to isolate $E$. coli, the real wastewater samples and soil samples suspension were cultured on MacConkey agar (MAC) using the streak plate method. Then the plates were incubated at $36 \pm 5^{\circ} \mathrm{C}$ for $24 \mathrm{~h}$. After the growth of the colonies, detection test was carried out to detect $E$. coli. To study biosorption, Mueller-Hinton Broth culture was prepared and poured into an Erlenmeyer flask $500 \mathrm{~mL}$ volume. After following sterilization at $121^{\circ} \mathrm{C}$ for $20 \mathrm{~min}$, E. coli colonies were inoculated into it and placed inside shaker-equipped incubator at $30{ }^{\circ} \mathrm{C}$ for $24 \mathrm{~h}$ at $150 \mathrm{rpm}$. To examine the bacterial colonies growth, optimal density (OD) was determined at the wavelength of $620 \mathrm{~nm}$ using a spectrophotometer.

\section{Biosorption studies}

$15 \mathrm{~mL}$ of the culture medium containing $E$. coli was added to $1 \mathrm{~g}$ of zeolite in an Erlenmeyer flask with $250 \mathrm{~mL}$ volume after that, $150 \mathrm{~mL}$ of different concentrations of copper and zinc (between 10 and $60 \mathrm{mg} / \mathrm{L}$ ) were added to this suspension. The solutions $\mathrm{pH}$ were measured. The flasks were stirred at $28{ }^{\circ} \mathrm{C}$ with a slow mixing rate $(150 \mathrm{rpm})$ for 10 days (the time required for reaching equilibrium according to studies). Then, $5 \mathrm{~mL}$ of the sample was centrifuged for $5 \mathrm{~min}$ at $4000 \mathrm{rpm}$ and the concentration of the residual metals was measured. The experiments were conducted with the real sample in the optimal conditions and the adsorption capacity was calculated. In order to control the absorption of biofilm and zeolite together, the adsorption experiments were also carried out for $40 \mathrm{mg} / \mathrm{L}$ of metal cations with zeolite alone.

\section{Results}

\section{Physical and chemical properties of wastewater}

The obtained results from measurement of temperature, $\mathrm{pH}$ and chemical parameters of the raw wastewater samples entering the neutralization unit and the output wastewater leaving the treatment plant of Bahonar Copper Complex are shown in Table 1.

\section{Characterization of zeolite}

The results of chemical analysis of the zeolite used in this study with XRF indicated that the percentages of the metal oxides constituting zeolite including $\mathrm{Al}_{2} \mathrm{O}_{3}, \mathrm{SiO}_{2}, \mathrm{SO}_{3}, \mathrm{CaO}$, $\mathrm{Cl}, \mathrm{Na}_{2} \mathrm{O}, \mathrm{K}_{2} \mathrm{O}$, L.O.I were 68.11, 30.17, 0.20, 0.08, 0.16, $19.54,0.14$ and $21.61 \%$, respectively. Furthermore, the results of XRD analysis are demonstrated in Fig. 1.

XRD spectrum resulting from zeolite indicated that clinoptilolite, quartz and cristobalite were the major minerals, while calcite and Montmorillonite are secondary minerals.

\section{The effect of $\mathrm{pH}$}

The $\mathrm{pH}$ values of the metal solutions were changed after mixing zeolite and the culture medium containing bacteria. The $\mathrm{pH}$ values of copper and zinc solutions were in the range of 5.4-6.1 and 5.7-5.3, respectively. After adding the culture medium containing $E$. coli, the concentration of copper and zinc decreased to $9.09,18.18,27.27,36.36,45.45$ and 54.54 due to alteration of volume.

The obtained results from comparison of the amounts of copper and zinc cations biosorption in a batch medium with mixture of $E$. coli and zeolite, copper and zinc concentration of $36.36 \mathrm{mg} / \mathrm{L}$, incubator temperature of $28^{\circ} \mathrm{C}$, shaker rate of $150 \mathrm{rpm}$ and incubation duration of 10 days indicated that the removal efficiencies of copper and zinc were 54.98 and $57.32 \%$, respectively. The adsorption

Table 1 The results of qualitative analysis of the input raw wastewater into the neutralization unit and the output wastewater leaving the treatment plant of Bahonar copper complex

\begin{tabular}{|c|c|c|c|c|c|c|}
\hline Wastewater & Heavy metals & $\begin{array}{l}\text { Range of changes in } \\
\text { concentration (mg/L) }\end{array}$ & $\begin{array}{l}\text { Range of changes } \\
\text { in TSS }(\mathrm{mg} / \mathrm{L})\end{array}$ & $\begin{array}{l}\text { Range of changes in } \\
\mathrm{COD}(\mathrm{mg} / \mathrm{L})\end{array}$ & $\begin{array}{l}\text { Range of changes in } \\
\text { BOD }(\mathrm{mg} / \mathrm{L})\end{array}$ & $\begin{array}{l}\text { Ranges of } \\
\text { changes in } \\
\mathrm{pH}\end{array}$ \\
\hline \multirow{2}{*}{$\begin{array}{l}\text { The input raw } \\
\text { wastewater into } \\
\text { neutralization } \\
\text { unit }\end{array}$} & $\mathrm{Cu}$ & $53.3 \pm 4.8$ & \multirow[t]{2}{*}{$299.6 \pm 16.3$} & \multirow[t]{2}{*}{$998.6 \pm 41.6$} & \multirow[t]{2}{*}{$725.4 \pm 56.2$} & \multirow[t]{2}{*}{$3.3 \pm 0.4$} \\
\hline & $\mathrm{Zn}$ & $61.4 \pm 5.7$ & & & & \\
\hline \multirow{2}{*}{$\begin{array}{l}\text { The output } \\
\text { wastewater of the } \\
\text { treatment plant }\end{array}$} & $\mathrm{Cu}$ & $3.1 \pm 0.3$ & \multirow[t]{2}{*}{$0.79 \pm 1.2$} & \multirow[t]{2}{*}{$190.4 \pm 16.4$} & \multirow[t]{2}{*}{$7.9 \pm 0.77$} & \multirow[t]{2}{*}{$6.2 \pm 0.3$} \\
\hline & $\mathrm{Zn}$ & $2.3 \pm 0.5$ & & & & \\
\hline
\end{tabular}


Fig. 1 XRD spectrum resulting from the utilized zeolite sample

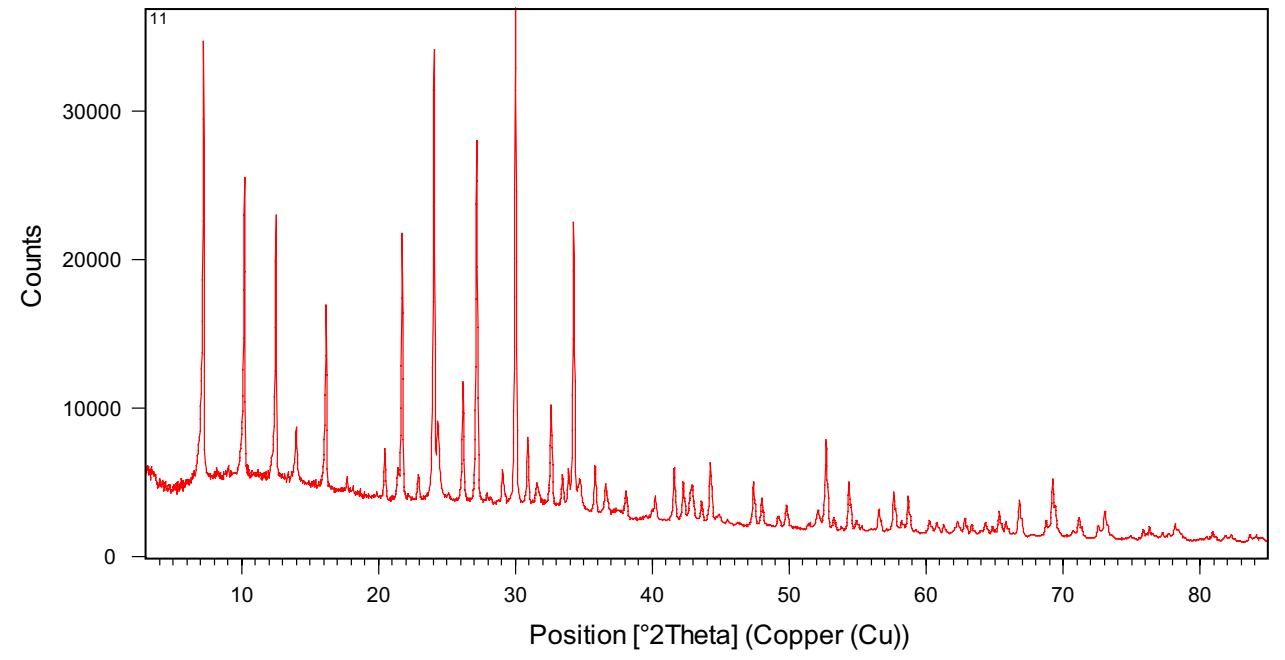

capacity of copper and zinc was obtained as 3.29 and $3.43 \mathrm{mg} / \mathrm{g}$, respectively.

The results obtained from the effect of $\mathrm{pH}$ on the adsorption capacity with the mixture of $E$. coli and zeolite biofilm at copper and zinc concentrations of $36.36 \mathrm{mg} / \mathrm{L}$, incubation duration of 10 days, incubation temperature of $28{ }^{\circ} \mathrm{C}$, and shaker rate of $150 \mathrm{rpm}$ indicated that the maximum removal efficiencies were obtained in $\mathrm{pH}$ values of 4.8-5.7 and 4.5-5.5 for copper and zinc, respectively. For both metals, the removal efficiency increased with elevation of $\mathrm{pH}$ up to 6 , which could be due to the appearance of negative charged ligands on the biofilm surface and adsorption of more metal cations. In $\mathrm{pH}$ values more than 6 , the removal efficiencies decreased.

\section{The effect of the initial concentration}

The obtained results from the effect of contact time and initial concentration of copper and zinc metal ions on the adsorption capacities with the $E$. coli biofilm placed on the zeolite in the metal concentration of $36.36 \mathrm{mg} / \mathrm{L}$, incubation temperature of $28^{\circ} \mathrm{C}$ and shaker rate of $150 \mathrm{rpm}$ are shown in Fig. 2.

In all of the experiments, metal ions removal was rapid within the initial hours, but it became slower and gradual in the next days. The equilibrium times in adsorption of copper and zinc were obtained after 5 and 4 days, respectively.

Investigation of the initial concentration effect on the copper and zinc biosorption with $E$. coli biofilm placed on the zeolite at incubation duration of 10 days, at $28{ }^{\circ} \mathrm{C}$, shaker rate of $150 \mathrm{rpm}$ revealed that for both metals, with the increase in the initial concentration from 10 to $60 \mathrm{mg} / \mathrm{L}$,
Fig. 2 The effect of contact time on the biosorption of $\mathrm{Cu}$ and $\mathrm{Zn}$ by $E$. coli biofilm on zeolite (metal concentration: $36.36 \mathrm{mg} / \mathrm{L}$, incubation temperature: $28^{\circ} \mathrm{C}$, shaker rate: $150 \mathrm{rpm}$ )

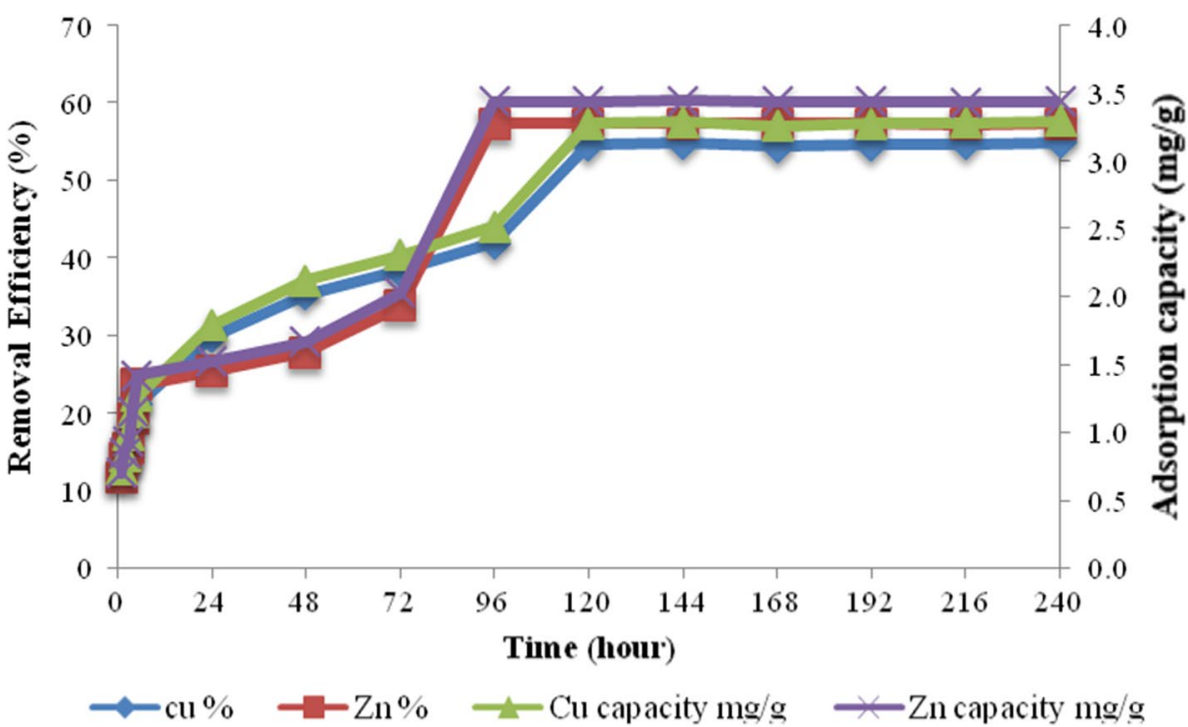


removal efficiency decreased from 71.40 to 35.91 and 67.86 to 37.07 , respectively.

\section{Adsorption isotherms}

The experimental data have been analyzed by the Langmuir and Freundlich adsorption isotherms. The results indicated that removal of metal cations of copper and zinc with $E$. coli biofilm placed on the zeolite was fitted with Langmuir and Freundlich adsorption isotherm with correlation coefficients of 0.98 and 0.95 , respectively. Figures 3 and 4 indicate Freundlich and Langmuir adsorption isotherms at the initial concentrations of $10,20,30,40,50$ and $60 \mathrm{mg} / \mathrm{L}$ of the metals, incubation duration of 10 days, at $28{ }^{\circ} \mathrm{C}$, and shaker rate of $150 \mathrm{rpm}$.

The parameters obtained from the adsorption isotherm models are shown in Table 2.

The results indicated that in the synthetic sample, with $40 \mathrm{mg} / \mathrm{L}$ concentration at the equilibrium time, the removal efficiencies for the bacteria-free sample and bacterial sample isotherm model (metal initial concentrations of $10,20,30$, 40,50 and $60 \mathrm{mg} / \mathrm{L}$, incubation duration of 10 days, incubation temperature of $28^{\circ} \mathrm{C}$, and shaker rate of $150 \mathrm{rpm}$ )
Fig. 3 Langmuir adsorption

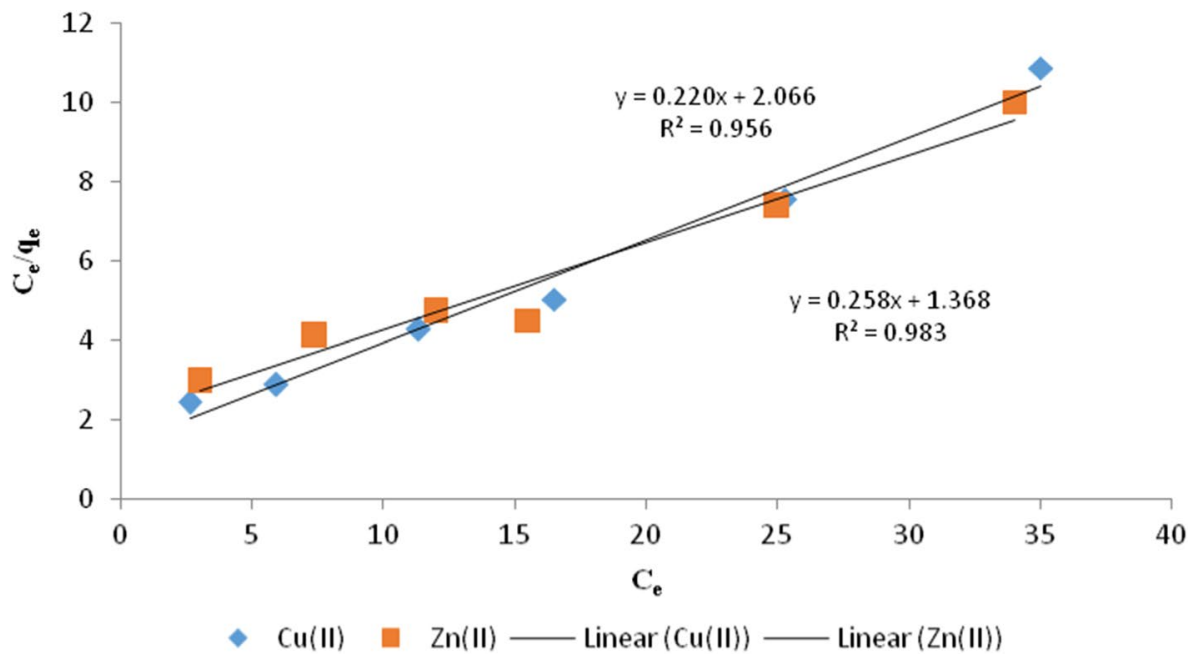

Fig. 4 Freundlich adsorption isotherm model (metal initial concentrations of $10,20,30$, 40,50 and $60 \mathrm{mg} / \mathrm{L}$, incubation duration of 10 days, incubation temperature of $28{ }^{\circ} \mathrm{C}$, and shaker rate of $150 \mathrm{rpm}$ )
Table 2 The parameters of Langmuir and Freundlich isotherms of adsorption of copper and zinc on E. coli biofilm and zeolite

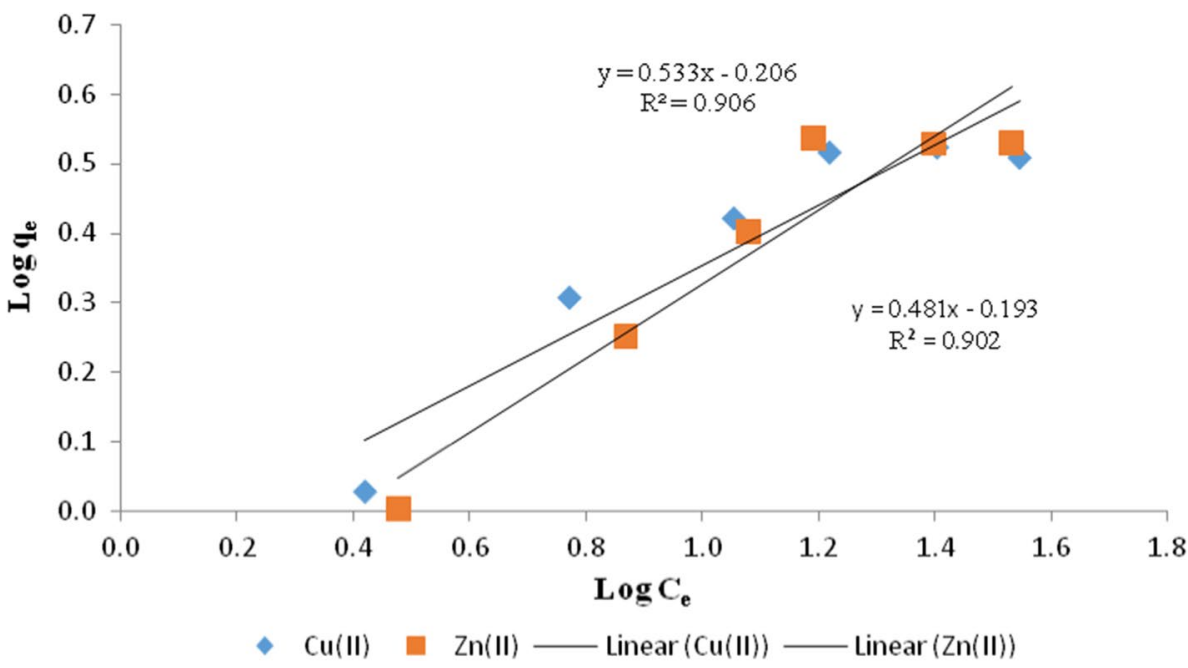

\begin{tabular}{|c|c|c|c|c|c|c|}
\hline \multirow[t]{2}{*}{ Isotherm model } & \multicolumn{3}{|c|}{ Parameter } & \multicolumn{3}{|c|}{ Parameter } \\
\hline & $\mathrm{Cu}(\mathrm{II}$ & & & $\mathrm{Zn}(\mathrm{II}$ & & \\
\hline \multirow[t]{2}{*}{ Langmuir isotherm } & $q_{\mathrm{m}}$ & $k_{\mathrm{L}}$ & $R^{2}$ & $q_{\mathrm{m}}$ & $k_{\mathrm{L}}$ & $R^{2}$ \\
\hline & 3.87 & 0.18 & 0.98 & 4.54 & 0.10 & 0.95 \\
\hline \multirow[t]{2}{*}{ Freundlich isotherm } & $N$ & $k_{\mathrm{f}}$ & $R^{2}$ & $n$ & $k_{\mathrm{f}}$ & $R^{2}$ \\
\hline & 2.08 & 0.82 & 0.90 & 1.87 & 0.18 & 0.90 \\
\hline
\end{tabular}


were obtained 41.52 and $54.61 \%$ for copper and 39.73 and 57.35 for zinc, respectively.

To study the copper and zinc metal cations removal in the real condition, the Bahonar Copper Complex wastewater was examined.

Usage of the input raw wastewater into the treatment plant as the real solution in the biosorption process indicated that the $E$. coli biofilm placed on the zeolite removed copper and zinc cations with removal efficiencies of 51.28 and $48.25 \%$, respectively. However, use of the output wastewater from the treatment plant as the real solution in the biosorption process showed that the hybrid system removed the copper and zinc cations with efficiencies of 94.75 and $92.96 \%$, respectively.

\section{Discussion}

The results showed that the copper and zinc adsorption capacities had a slight difference. Several factors affect the adsorption of the metal cations including the zeolite surface negative charge in water (Quintelas et al. 2009a, b) and bacteria, metal valence, electronegativity, atomic weight and the metal ionic radius (Quintelas et al. 2008). Copper and zinc are two transition elements, which have similar atomic radius to some extent and are mostly presented in the form of bivalent ions (Huse et al. 2012). Therefore, the adsorption capacities for both metals were almost the same. Quintelas et al. (2009a, b) examined biosorption of chromium, cadmium, iron and nickel with $E$. coli biofilm placed on zeolite NaY in Portugal. They expressed difference in the adsorption capacities of metals from the chemical properties of each metal including the valence and atomic weight of metals and also biomass properties including the structure, functional groups and surface area (Quintelas et al. 2009a, b). Also, Quintelas et al. (2011) used E. coli placed on $\mathrm{NaY}$ zeolite and optimized the biofilm of Artherobacter Viscose bacteria fixed on Zeolite 13x for removal of heavy metals (Quintelas et al. 2009a, b, 2011). The results indicated that by increasing the metal ions concentration, the adsorption capacity increased, while the efficiency decreased. Basak et al. (2014) used yeast fixed on gravel for zinc ions removal and obtained similar results. They stated that in the adsorption process, the initial concentration of the adsorbate metal ions plays a key role in the solution and with the increase in the initial concentration of zinc ion, the driving force required for overcoming the resistance of mass transfer of metal ions between the aqueous and solid phases grows (Basak et al. 2014). The results of these studies are in consistent with the results of this study.

Buasri et al. (2012) in Thailand used Water Hyacinth for removal of bivalent copper and zinc cations. At concentrations above 1000 and $750 \mathrm{ppm}$ for copper and zinc, respectively, they did not show a significant increase. In their opinion, at higher concentrations, active sites available on the biosorbent, increase in contact time and the available metal ions, the efficiency did not have a considerable increase (Buasri et al. 2012).

Availability of groups with negative charges on the surface of the biosorbent is essential in removal of heavy metals. Thus, $\mathrm{pH}$ is one of the most influential factors in biosorption (Deng et al. 2007).

Adsorption of metals with changes in $\mathrm{pH}$ depends on the chemistry of metals in the solution and ionic state of the functional groups of the adsorbent on available hybrid positions (Adeli et al. 2012). The low removal efficiency in acidic $\mathrm{pH}$ values is due to competition between $\mathrm{H}^{+}$ions and metal cations of $\mathrm{Cu}^{2+}$ and $\mathrm{Zn}^{2+}$ for the adsorbent's active sites.

The removal efficiency decreased significantly at $\mathrm{pH}=8.5$ for both metals. Quintelas et al. (2009a, b) in Portugal used $E$. coli biofilm placed on $\mathrm{NaY}$ zeolite for removal of nickel(II), iron(III), cadmium(II) and chromium(VI). At the optimal $\mathrm{pH}$ of 6 , the maximum removal efficiencies were obtained for nickel and cadmium 82.5 and $65 \%$, respectively, at concentrations of $10-100 \mathrm{mg} / \mathrm{L}$, which approved our results (Quintelas et al. 2009a, b).

Mishra et al. (2013) in India used sludge of wastewater for removal of zinc ion. The results indicated that in $\mathrm{pH}$ values in range of 2-5.3 the removal efficiency showed an ascending trend, and at $\mathrm{pH}=5.2$, the maximum efficiency was obtained for the concentration of $20 \mathrm{mg} / \mathrm{L}$. They attributed the low removal percentage in $\mathrm{pH}$ values below 5 to dominance of repulsion force between the adsorbent and adsorbate. Furthermore, the reason of removal percentage in $\mathrm{pH}$ values more than 6 was attributed to the possibility of deposition of zinc ions on the adsorbent surface (Mishra et al. 2013)

Sag and Kutsal (1996) in Turkey obtained the maximum removal of copper at $\mathrm{pH}=4$ with the initial concentration of $50 \mathrm{mg} / \mathrm{L}$ by R. arrhizus (Sag and Kutsal 1996).

Salehizadeh and Shojaosadati (2003) in Iran used polysaccharides produced from Bacillus Firmus bacteria for copper and zinc removal. They attributed the increase in adsorption of metals with the increase in the initial $\mathrm{pH}$ to the reaction between cations, and negative charges of the acidic polysaccharide functional groups and for reduction in adsorption in alkaline range of $\mathrm{pH}$ to the start of formation insoluble hydroxides (Salehizadeh and Shojaosadati 2003).

Figueiredo et al. (2008) in Portugal used zeolite in biosorption. They stated that existence of large values of $\mathrm{Na}_{2} \mathrm{O}$ in zeolite is responsible for the reduction of $\mathrm{pH}$ in the solution, which $\mathrm{pH}$ plays essential role in biosorption (Figueiredo et al. 2008).

Study of adsorption isotherms in biosorption is essential for industrial uses in order to compare different biological materials under different operational conditions 
(Quintelas et al. 2009a, b). In order to optimize the adsorption system design for removal of contaminants from real wastewater, a rational relationship between equilibrium curves should be obtained (Rosales et al. 2011). Based on Figs. 3 and 4, the results indicated that the experimental data of biosorption of copper and zinc cations revealed better results with the Langmuir isotherm with correlation coefficients of $\left(R^{2}=0.968\right)$, when compared with the Freundlich isotherm $\left(R^{2}=0.921\right)$. These results approved with Abdel Salam et al., Figueiredo et al., as well as Quintelas et al. (2009a, b; Abdel Salam et al. 2011; Figueiredo et al. 2008).

Based on Table 1, measurement of the levels of copper and zinc in the input raw wastewater entering the treatment plant with active sludge process and the output wastewater leaving the treatment plant indicated that the removal efficiencies in the treatment plant were $92.84 \%$ and $95 \%$ for copper and zinc, respectively. Usage of real samples in the biosorption process had efficiencies of $51.28 \%$ and $48.25 \%$ for copper and zinc from the input raw wastewater into the treatment plant and $94.75 \%$ and $92.96 \%$ for copper and zinc from the treatment plant's output wastewater.

The results indicated that the removal efficiency is lower in real samples with the biosorption process in comparison with the synthetic sample and the time required for reaching equilibrium is longer. Indeed, the removal process of metals is disrupted with the presence of other ions. Presence of several metals resulted in an interactive effect, whereby there are three interfering effects; mixed effects which are more than the effects of individual ions (intensifying) or lower (reducing), or inert (without interaction) (Sag and Kutsal 1996).

Sag and Kutsal (1996) in Turkey investigated the effect of selective biosorption of a mixture containing copper and chromium ions. They found that concurrent removal of these two ions reaches equilibrium within a longer period of time, but chromium ions have an interfering effect on the removal of copper ions, which is different with our results. They stated that as the optimal $\mathrm{pH}$ and chemical characteristics of metal ions differ from each other, their concurrent adsorption in the compound mixture is noncompetitive (Sag and Kutsal 1996).

Salehizade et al. (2003) in Iran examined the effect of presence of metal ions together in an aqueous solution on the adsorption capacity by polysaccharides produced from Bacillus Firmus. They found that the removal efficiency of each metal is lower in the mixture containing the metal ions of copper, zinc and lead, when compared with the removal efficiency of each individual ion alone, and the metals in the mixture have an interfering effect on biosorption. Moreover, Bacillus Firmus is a nonspecific bacterium and has the same behavior with all metal ions (Salehizadeh and Shojaosadati 2003).

\section{Conclusion}

The results showed that use of the hybrid system of $E$. coli biofilm placed on the zeolite has a better efficiency for copper and zinc cations removal in the wastewater with a low concentration of these ions. Therefore, it is recommended that in active sludge systems, if the output concentration of the mentioned metals is not within the environmental standards, this method be used for lowering their concentration.

Acknowledgements This research was conducted at the Environmental Health Engineering Research Center and was sponsored by the Vice Chancellor for Research and Technology of Kerman University of Medical Sciences. The authors' appreciation is expressed here to the Vice Chancellor and to all university staff who provided assistance to make this study possible. Hereby, their supports which have always been facilitator for this research are highly appreciated. Moreover, the cooperation of Kerman Bahonar Copper Complex which undertook collection of the study samples is also highly appreciated.

Open Access This article is licensed under a Creative Commons Attribution 4.0 International License, which permits use, sharing, adaptation, distribution and reproduction in any medium or format, as long as you give appropriate credit to the original author(s) and the source, provide a link to the Creative Commons licence, and indicate if changes were made. The images or other third party material in this article are included in the article's Creative Commons licence, unless indicated otherwise in a credit line to the material. If material is not included in the article's Creative Commons licence and your intended use is not permitted by statutory regulation or exceeds the permitted use, you will need to obtain permission directly from the copyright holder. To view a copy of this licence, visit http://creativecommons.org/licenses/by/4.0/.

\section{References}

Abdel Salam M, SI Makki M, YA Abdelaal M (2011) Preparation and characterization of multi-walled carbon nanotubes/chitosan nanocomposite and its application for the removal of heavy metals from aqueous solution. J Alloys Compd 509:2582-2587. https:// doi.org/10.1016/j.jallcom.2010.11.094

Adeli M, Yamini Y, Faraji M (2012) Removal of copper, nickel and zinc by sodium dodecyl sulphate coated magnetite nanoparticles from water and wastewater samples. Arab J Chem 1:1-31. https ://doi.org/10.1016/j.arabjc.2012.10.012

Ahmadi M, Jorfi S, Azarmansuri A, Jaafarzadeh N, Mahvi AH, Darvishi Cheshmeh Soltani R, Akbari H, Akhbarizadeh R (2017) Zoning of heavy metal concentrations including $\mathrm{Cd}, \mathrm{Pb}$ and $\mathrm{As}$ in agricultural soils of Aghili plain, Khuzestan province, Iran. Data Brief 14:20-27. https://doi.org/10.1016/j.dib.2017.07.008

American Public Health Association (1999) Standard methods for the examination of water and wastewater, vol. 4, 20th edn. APHA, AWWA, WEF, Washington, pp 4-83

Basak G, Lakshmi V, Chandran P, Das N (2014) Removal of Zn(II) from electroplating effluent using yeast biofilm formed on gravels: batch and column studies. Environ Health Sci Eng 12:8-19. https ://doi.org/10.1186/2052-336x-12-8

Buasri A, Chaiyut N, Tapang K, Jaroensin S, Panphrom S (2012) Biosorption of heavy metals from aqueous solutions using water hyacinth as a low cost biosorbent. Civ Environ Res 2:17-25. https ://doi.org/10.1016/j.apcbee.2012.06.046

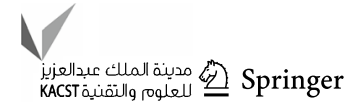


Deng X, Yi X, Liu G (2007) Cadmium removal from aqueous solution by gene-modified Escherichia coli JM109. J Hazard Mater 139:340-344. https://doi.org/10.1016/j.jhazmat.2006.06.043

Diagomanolin V, Farhang M, Ghazi-Khansari M, Jafarzadeh N (2004) Heavy metals $(\mathrm{Ni}, \mathrm{Cr}, \mathrm{Cu}$ ) in the Karoon waterway river, Iran. Toxicol Lett 151:63-67. https://doi.org/10.1016/j.toxle t.2004.02.018

Figueiredo H, Silva B, Quintelas C, Neves IC, Tavares M (eds) (2008) Biosorption of Cr VI supported on mordenite zeolite. In: 10 th international chemical and biological engineering conference. Braga, Portugal

Figueiredo H, Silva B, Quintelas C, Neves IC, Tavares T (2010) Effect of the supporting zeolite structure on $\mathrm{Cr}$ biosorption: performance of a single-step reactor and of a sequential batch reactor-a comparison study. Chem Eng J 163:22-27. https://doi.org/10.1016/j. cej.2010.07.015

Fu F, Wang Q (2011) Removal of heavy metal ions from wastewaters: a review. J Environ Manag 92:407-418

Huse M, Skilbred A, Karlsson M, Eriksson S, Norby T, Haugsrud R, Knee C (2012) Neutron diffraction study of the monoclinic to tetragonal structural transition in $\mathrm{LaNbO} 4$ and its relation to proton mobility. J Solid State Chem 187:27-34. https://doi. org/10.1016/j.jssc.2011.12.025

Kamsonlian S, Balomajumder C, Chand S, Suresh S (2011) Biosorption of $\mathrm{Cd}(\mathrm{II})$ and $\mathrm{As}(\mathrm{III})$ ions from aqueous solution by tea waste biomass. Afr J Environ Sci Technol 5:1-7

Lameiras S, Quintelas C, Tavares T (2008) Biosorption of Cr(VI) using a bacterial biofilm supported on granular activated carbon and on zeolite. Bioresour Technol 99:801-806. https://doi.org/10.1016/j. biortech.2007.01.040

Malakootian M, Almasi A, Hossaini $\mathrm{H}$ (2008) $\mathrm{Pb}$ and Co removal from paint industries effluent using wood ash. Int J Environ Sci Technol 5:217-222. https://doi.org/10.1007/bf03326015

Malakootian M, Ghadiri S, Yousefi N et al (2012) Isotherms and kinetics studies of biosorption nickel(II) and chromium(VI) from aqueous solution by dried activated sludge. Int J Environ Health Eng 1:20-25. https://doi.org/10.4103/2277-9183.94386

Malakootian M, Darabi-Fard Z, Amirmahani N, Nasiri A (2015a) Evaluation of arsenic, copper, lead, cadmium, and iron concentration in drinking water resources of central and Southern Bardsir plain, Iran, in 2014. J Kerman Univ Med Sci 22:542-554

Malakootian M, Yousefi N, Fatehizadeh AW, Van Ginkel S, Ghorbani M, Rahimi S, Ahmadian M (2015b) Nickel(II) removal from industrial plating effluent by Fenton process. Environ Eng Manag J 14:837-842. https://doi.org/10.30638/eemj.2015.093

Mishra U, Paul S, Bandyopadhaya M (2013) Removal of zinc ions from wastewater using industrial waste sludge: a novel approach. Environ Prog Sustain Energy 32:576-586. https://doi.org/10.1002/ ep. 11665

Munoz A, Ruiz E, Abriouel H, Gálvez A, Ezzouhri L, Lairini K, Espínola F (2012) Heavy metal tolerance of microorganisms isolated from wastewaters. Identification and evaluation of its potential for biosorption. Chem Eng J 210:325-332. https://doi. org/10.1016/j.cej.2012.09.007

Plaza J, Bernardelli C, Viera M, Donati E, Guibal E (2012) Zinc and cadmium biosorption by untreated and calcium-treated Macrocystis pyrifera in a batch system. Bioresour Technol 116:195-203. https://doi.org/10.1016/j.biortech.2012.04.014
Quintelas C, Fernandes B, Castro J, Figueiredo H, Tavares T (2008) Biosorption of $\mathrm{Cr}(\mathrm{VI})$ by a Bacillus coagulans biofilm supported on granular activated carbon (GAC). Chem Eng J 136:195-203. https://doi.org/10.1016/j.cej.2007.03.082

Quintelas C, Fonseca B, Silva B, Figueiredo H, Tavares T (2009a) Treatment of chromium(VI) solutions in a pilot-scale bioreactor through a biofilm of Arthrobacter viscosus supported on GAC. Bioresour Technol 100:220-226. https://doi.org/10.1016/j.biort ech.2008.05.010

Quintelas C, Rocha Z, Silva B, Fonseca B, Figueiredo H, Tavares T (2009b) Biosorptive performance of an Escherichia coli biofilm supported on zeolite $\mathrm{NaY}$ for the removal of $\mathrm{Cr}(\mathrm{VI})$, $\mathrm{Cd}(\mathrm{II}), \mathrm{Fe}(\mathrm{III})$ and Ni(II). Chem Eng J 152:110-115. https://doi. org/10.1016/j.cej.2009.03.039

Quintelas C, da Silva VB, Silva B, Figueiredo H, Tavares T (2011) Optimization of production of extracellular polymeric substances by Arthrobacter viscosus and their interaction with a $13 \mathrm{X}$ zeolite for the biosorption of $\mathrm{Cr}(\mathrm{VI})$. Environ Technol 32:1541-1549. https://doi.org/10.1080/09593330.2010.543930

Quintelas C, Pereira R, Kaplan E, Tavares T (2013) Removal of Ni(II) from aqueous solutions by an Arthrobacter viscosus biofilm supported on zeolite: from laboratory to pilot scale. Bioresour Technol 142:368-374. https://doi.org/10.1016/j.biortech.2013.05.059

Rosales E, Pazos M, Sanromán M, Tavares T (2011) Application of zeolite-Arthrobacter viscosus system for the removal of heavy metal and dye: chromium and Azure B. Desalination 284:150156. https://doi.org/10.1016/j.desal.2011.08.049

Sag Y, Kutsal T (1996) The selective biosorption of chromium(VI) and copper(II) ions from binary metal mixtures by $R$. arrhizus. Process Biochem 31:561-572. https://doi.org/10.1016/s0032 -9592(95)00100-X

Salehizadeh H, Shojaosadati S (2003) Removal of metal ions from aqueous solution by polysaccharide produced from bacillus firmus. Water Res 37:4231-4235. https://doi.org/10.1016/S0043 -1354(03)00418-4

Silva B, Figueiredo H, Quintelas C, Neves IC, Tavares T (2012) Improved biosorption for $\mathrm{Cr}(\mathrm{VI})$ reduction and removal by Arthrobacter viscosus using zeolite. Int Biodeterior Biodegrad 74:116-123. https://doi.org/10.1016/j.ibiod.2012.05.026

Tavares MT, Quintelas C, Figueiredo H, Neves I (2006) Comparative study between natural and artificial zeolites as supports for biosorption systems. Mater Sci Forum. https://doi.org/10.4028/ www.scientific.net/MSF.514-516.1294

Wang Y, Qiao M, Liu Y, Zhu Y (2012) Health risk assessment of heavy metals in soils and vegetables from wastewater irrigated area, Beijing-Tianjin city cluster, China. J Environ Sci 24:690-698. https ://doi.org/10.1016/S1001-0742(11)60833-4

Wang L, Lachawiec A Jr, Yang R (2013) Nanostructured adsorbents for hydrogen storage at ambient temperature: high-pressure measurements and factors influencing hydrogen spillover. RSC Adv 46:23935-23952. https://doi.org/10.1039/C3RA44216K

Publisher's Note Springer Nature remains neutral with regard to jurisdictional claims in published maps and institutional affiliations. 